Check for updates

Cite this: RSC Adv., 2018, 8, 35056

Received 21st September 2018 Accepted 8th October 2018

DOI: $10.1039 / \mathrm{c} 8 \mathrm{ra0} 07841 \mathrm{f}$

rsc.li/rsc-advances

\title{
Substrate switchable Suzuki-Miyaura coupling for benzyl ester vs. benzyl halide $\uparrow$
}

\begin{abstract}
Masato Ohsumi, ${ }^{\text {ab }}$ Akitaka Ito (iD ${ }^{\text {bc }}$ and Nagatoshi Nishiwaki (D)*bc
Two reaction conditions were developed to accomplish the substrate switchable Suzuki-Miyaura coupling of benzyl derivatives and arylboronic acid derivatives. Under conditions for esters, benzyl esters such as carbonates and acetates reacted with arylboronic acids to afford the corresponding diarylmethanes. However, the benzyl halides did not react under the same conditions. On the other hand, benzyl halides such as bromides and chlorides furnished diarylmethanes under conditions for halides, under which benzyl ester substrates did not react, in which water was found to play an important role. This switching system was tested using the intermolecular/intramolecular competitive reactions, during which the desired products could be synthesized by selecting the appropriate reaction conditions.
\end{abstract}

\section{Introduction}

Diarylmethanes are an important class of compounds because they are widely used as a framework for functional materials including polymers, ${ }^{1}$ dyes, ${ }^{2}$ and biologically active compounds. ${ }^{3}$ Various methods have been reported for their synthesis, including the Suzuki-Miyaura coupling reaction, which has become our focus. $^{4-6}$ In a typical Suzuki-Miyaura coupling, benzyl esters (carbonates or acetates) are reacted with arylboronic acids in the presence of a Pd catalyst under air atmosphere to efficiently afford the corresponding diarylmethanes. ${ }^{5}$ In our protocol, the Pd catalyst is prepared from inexpensive and commercially available $\mathrm{PdCl}_{2}$ and bidentate bis(phosphine) ligands. The ability to use an accessible catalyst improved the practicality of the reaction. Moreover, the reactivity of the benzyl esters was found to be between that of chloro- and bromobenzenes. This property facilitated the selective synthesis of benzyl(biphenyl)s by successive Suzuki-Miyaura coupling reactions (Scheme 1). These results prompted us to investigate a more challenging project; controlling chemoselectivity for benzyl esters and benzyl halides. In this study, we managed to successfully switch the substrate favored for coupling by changing the reaction conditions.

${ }^{a}$ Kochi National College of Technology, Nankoku, Kochi 783-8508, Japan

${ }^{b}$ School of Environmental Science and Engineering, Kochi University of Technology, Miyanokuchi, Tosayamada, Kami, Kochi 782-8502, Japan. E-mail: nagatoshi. nishiwaki@kochi-tech.ac.jp

${ }^{c}$ Research Center for Material Science and Engineering, Kochi University of Technology, Miyanokuchi, Tosayamada, Kami, Kochi 782-8502, Japan

$\dagger$ Electronic supplementary information (ESI) available: Experimental data for optimization of the reaction conditions, for chemoselective coupling reactions using other substrates; copies of ${ }^{1} \mathrm{H}$ and ${ }^{13} \mathrm{C}$ NMR spectra. See DOI: 10.1039/c8ra07841f

\section{Results and discussion}

When benzyl carbonate $\mathbf{1 A}$ was reacted with phenylboronic acid (5a) (1.25 equiv.) in the presence of the Pd catalyst derived from $\mathrm{PdCl}_{2}$ (5 mol\%) and DPEPhos (5.5 mol\%) in ethanol, the coupling reaction proceeded to afford diarylmethane $\mathbf{6} \mathbf{A a}^{4 f}$ in a $76 \%$ yield after heating at $80{ }^{\circ} \mathrm{C}$ for $1 \mathrm{~d}$ (Table 1 , entry 1$)$. These conditions are referred to as conditions for esters, in which lack of any reagent did not undergo the reaction at all. Although benzyl acetate $2 \mathbf{A}$ reacted similarly, its reactivity was lower than that of carbonate $\mathbf{1 A}$ (entry 2). On the other hand, benzyl halides 3A and 4A did not react under the same conditions (entries 3 and 4). After surveying several reaction condition options, the choice of ligand, base, and solvent was found to be crucial to

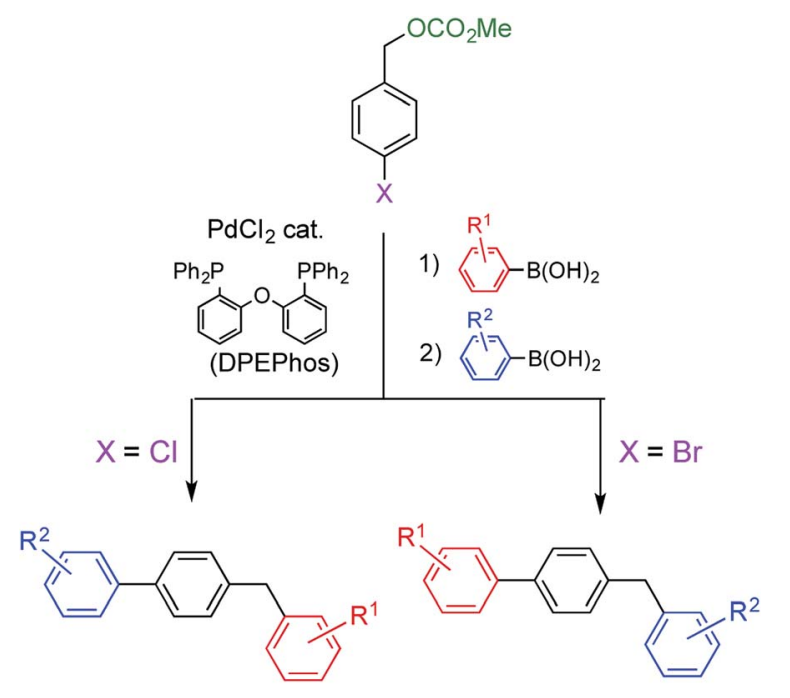

Scheme 1 Chemoselective synthesis of benzyl(biphenyl)s. 
Table 1 Assessment of switchable reaction conditions depending on the substrate

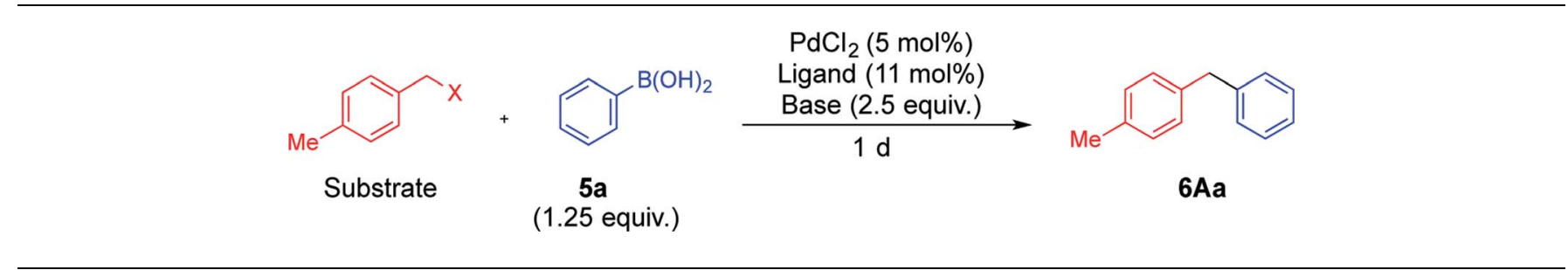

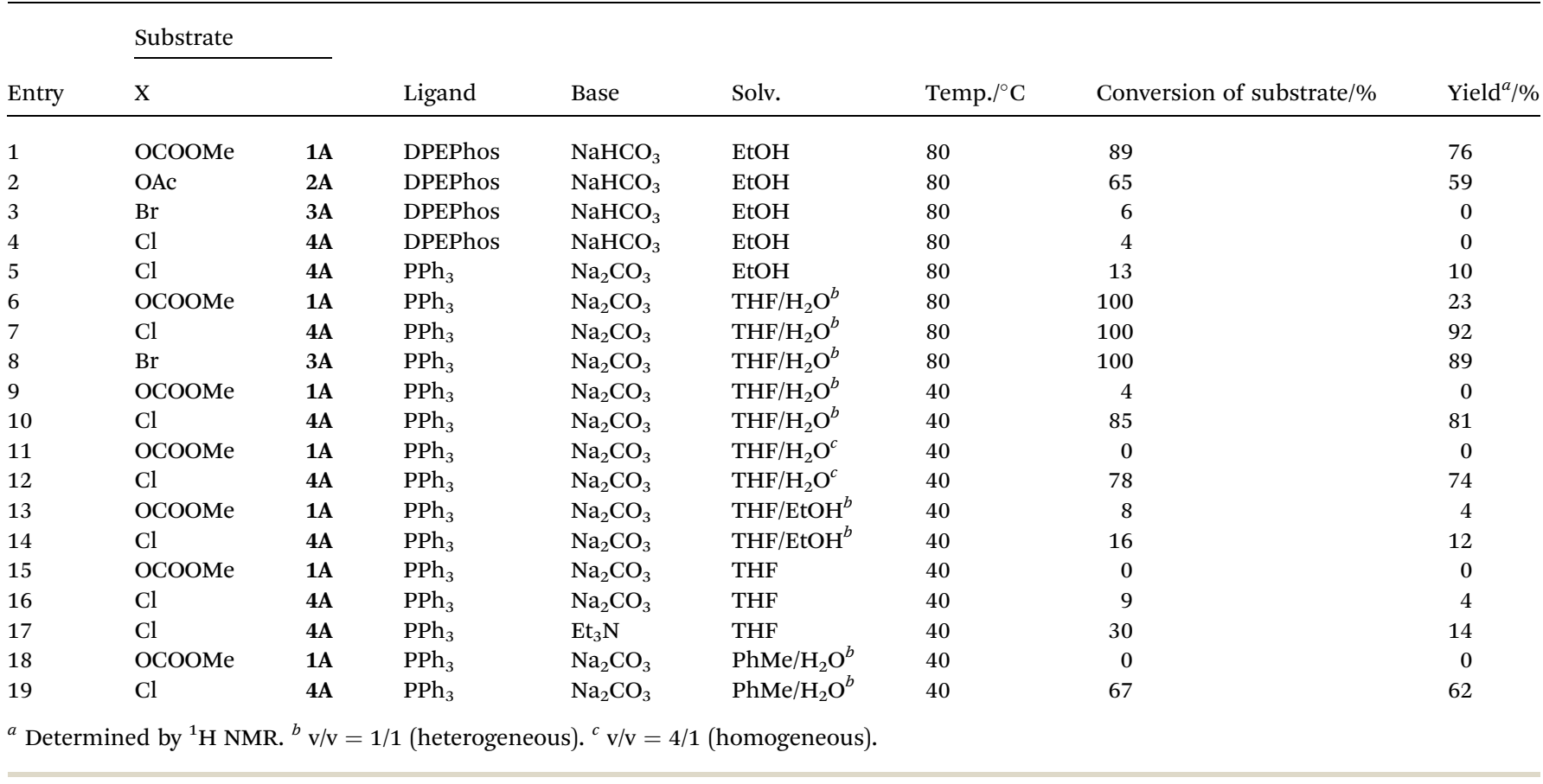

switching the reactivity (Table $\mathrm{S} 1$ in the ESI $\dagger$ ). A combination of triphenylphosphine and $\mathrm{Na}_{2} \mathrm{CO}_{3}$ facilitated the reaction of benzyl chloride $\mathbf{4 A}$ (entry 5). A complete switch was made to afford 6Aa efficiently while 1A did not react (entries 6-10; successful reactions were performed in a mixed THF/water $(\mathrm{v} / \mathrm{v}$ $=1 / 1)$ solvent at $40{ }^{\circ} \mathrm{C}$, referred to conditions for halides). Benzyl bromide 3A showed similar behavior to $\mathbf{4 A}$ to undergo the coupling reaction efficiently only under conditions for halides (entry 8). Usually, THF and water is miscible; however, a mixed solvent $(\mathrm{v} / \mathrm{v}=1 / 1)$ was separated into two layers in this reaction. On the other hand, the yields of 6Aa were considerably lower in reactions performed using a homogeneous mixed solvent of THF and water $(\mathrm{v} / \mathrm{v}=4 / 1)$, THF and ethanol $(\mathrm{v} / \mathrm{v}=1 / 1)$ or THF alone (entries 11-16). In addition, triethylamine was not an effective base for this reaction (entry 17). To the contrary, the reaction proceeded more efficiently when a mixed solvent of toluene and water $(\mathrm{v} / \mathrm{v}=1 / 1)$ was employed (entries 18 and 19). Based on these results, the presence of water was found to be crucial for this reaction. Although there is a report that aqueous conditions are effective for the reaction using DPEPhos, exact role of water was not mentioned. ${ }^{7}$

In order to obtain insights for the role of water, density functional theory (DFT) calculation using B3LYP was performed for two plausible intermediate complexes $\left[\mathrm{PdBnCl}\left(\mathrm{PPh}_{3}\right)_{2}\right.$ ] $\left(+\mathrm{H}_{2} \mathrm{O}\right)$ and $\left[\mathrm{PdBnCl}\left(\mathrm{PPh}_{3}\right)\left(\mathrm{OH}_{2}\right)\right]\left(+\mathrm{PPh}_{3}\right)($ Table 2, Fig. 1 and 2).
By comparing the $\Delta G_{\text {tot }}$ values of these complexes, the latter is thermodynamically favored by $-\Delta G_{\text {tot }}=0.032521$ a.u. (20.4 kcal mol $\left.{ }^{-1}\right)$.

It is considered that different reactivity between benzyl esters and benzyl halides are brought about different mode during the oxidative addition steps in the catalytic cycle. When benzyl carbonate 1A undergoes oxidative addition to $\mathrm{Pd}^{0}$ species, $\pi$ complex 7 is formed accompanied by decarboxylation (Scheme 2, eqn (1)). Benzyl acetate $\mathbf{2 A}$ also affords similar complex intermediately. On the other hand, in cases of benzyl chloride 4A, $\sigma$-complex 8 is formed, and benzyl bromide $3 \mathbf{A}$ also affords similar complex. One of the phosphine ligands in $\mathbf{8}$ is easily exchanged with water leading to complex $\mathbf{9}$, which undergoes the subsequent coupling reaction efficiently (eqn (2)).

Other benzyl derivatives 1-4 were coupled under the conditions optimized for 4-methylbenzyl carbonate $\mathbf{1 A}$ (conditions for esters) or 4-methylbenzyl chloride 4A (conditions for halides), and each reaction proceeded in high conversion yield (Table 3). Under conditions for esters, benzyl carbonates $\mathbf{1}$ and benzyl acetates 2 exhibited similar reactivity to afford the corresponding diarylmethanes 6 in comparable yields; however, benzyl halides 3 and 4 did not react except for highly reactive methoxy derivatives 3B and 4B (Table S2 in ESI + ). To the contrary, only benzyl halides $\mathbf{3}$ and $\mathbf{4}$ coupled under conditions for halides, and no reaction was observed when benzyl esters 1 
Table 2 Thermodynamic parameters of $\left[\mathrm{PdBnCl}\left(\mathrm{PPh}_{3}\right) \mathrm{L}\right]$

\begin{tabular}{lllr}
\hline Compound & $E_{0}{ }^{a} /$ a.u. & $G_{\text {corr }}{ }^{a} /$ a.u. & $G_{\text {tot }}{ }^{a} /$ a.u. \\
\hline$\left[\mathrm{PdBnCl}\left(\mathrm{PPh}_{3}\right)\left(\mathrm{OH}_{2}\right)\right]$ & -1970.727043 & +0.356655 & -1970.370388 \\
$\mathrm{PPh}_{3}$ & -1036.322130 & +0.227447 & -1036.094683 \\
{$\left[\mathrm{Pd}(\mathrm{Bz}) \mathrm{Cl}\left(\mathrm{PPh}_{3}\right)\left(\mathrm{OH}_{2}\right)\right]\left(+\mathrm{PPh}_{3}\right)$} & & & -3006.465071 \\
{$\left[\mathrm{PdBnCl}\left(\mathrm{PPh}_{3}\right)_{2}\right]$} & -2930.603622 & +0.587757 & -2930.015865 \\
$\mathrm{H}_{2} \mathrm{O}$ & -76.419737 & +0.003052 & -76.416685 \\
{$\left[\mathrm{PdBnCl}\left(\mathrm{PPh}_{3}\right)_{2}\right]\left(+\mathrm{H}_{2} \mathrm{O}\right)$} & & & -3006.432550
\end{tabular}

${ }^{a} E_{0}$ : total electronic energy, $G_{\text {corr: }}$ thermal correction to Gibbs free energy, $G_{\text {tot }}$ sum of electronic and thermal free energies.
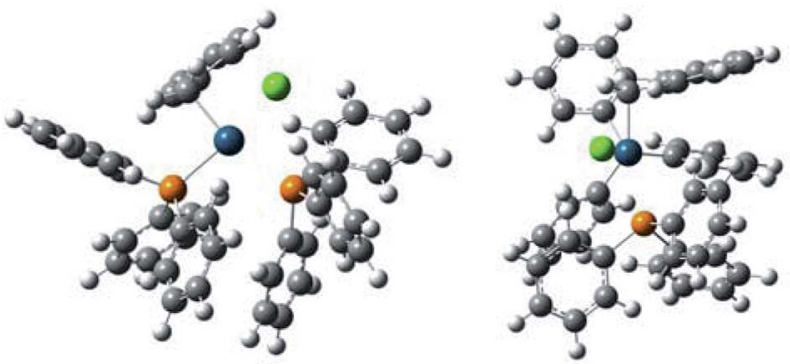

Fig. 1 Optimized geometry of $\left[\mathrm{PdBnCl}\left(\mathrm{PPh}_{3}\right)_{2}\right]$ : top view (left) and side view (right).
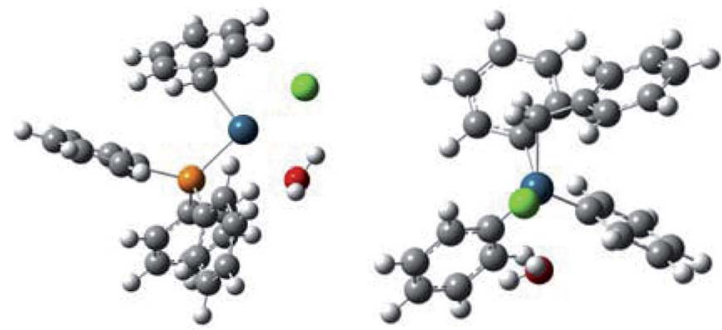

Fig. 2 Optimized geometry of [PdBnCl(PPh $\left.)\left(\mathrm{OH}_{2}\right)\right]$ : top view (left) and side view (right).

(1)

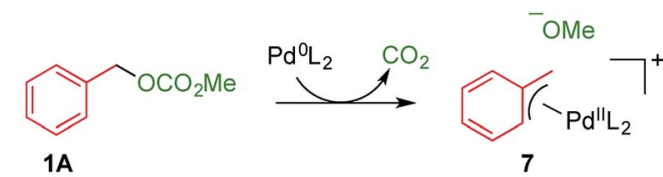

(2)

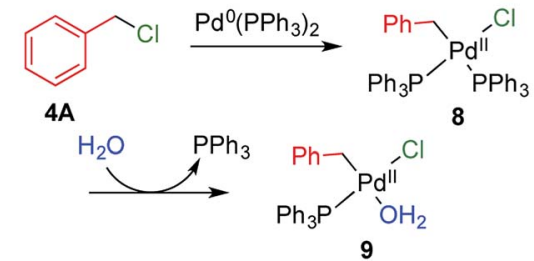

Scheme 2 Plausible intermediate complexes in the coupling reactions using benzyl carbonate $1 \mathrm{~A}$ and benzyl chloride $4 \mathrm{~A}$.

and 2 were employed (Table S3 in ESI $\dagger$ ). In cases of the less reactive, electron-deficient benzyl chlorides $\mathbf{4 C - F}$, yields of diarylmethanes $\mathbf{6 C a}-\mathbf{F a}$ were higher than those obtained in the reactions using $\mathbf{1 C}-\mathbf{F}$ under conditions for esters.
When other boronic acids, $\mathbf{5 b}$-d, were reacted under conditions for esters, carbonate $\mathbf{1 A}$ and acetate $\mathbf{2 A}$ afforded diarylmethanes $\mathbf{6 A b}-\mathbf{A d}$ while halides $\mathbf{3 A}$ and $\mathbf{4 A}$ did not afford $\mathbf{6}$ (Tables 4 and $\mathrm{S} 4$ in ESI $\dagger$ ). The coupling reactions were not influenced by the electronic properties of the substituents on the boronic acids $\mathbf{5}$. On the other hand, $\mathbf{1 A}$ and $\mathbf{2 A}$ were

Table 3 Chemoselective coupling reactions using benzyl carbonates 1 and benzyl chlorides $4^{a}$

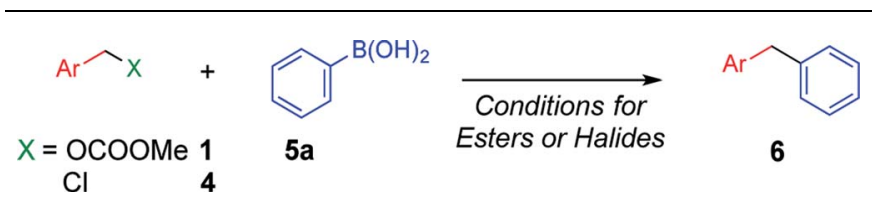

Reactions of esters $\mathbf{1}^{b}$

\begin{tabular}{|c|c|c|c|c|c|}
\hline \multirow[b]{2}{*}{ Entry } & \multicolumn{2}{|c|}{ Benzyl carbonate } & \multirow{2}{*}{$\begin{array}{l}\text { Conversion } \\
\text { of } \mathbf{1} / \%\end{array}$} & \multicolumn{2}{|c|}{ Product } \\
\hline & $\mathrm{Ar}$ & & & & Yield/\% \\
\hline 1 & $\begin{array}{l}4- \\
\mathrm{MeOC}_{6} \mathrm{H}_{4}\end{array}$ & 1B & 100 & $6 \mathbf{B a}^{4 c}$ & 92 \\
\hline 2 & $4-\mathrm{CF}_{3} \mathrm{C}_{6} \mathrm{H}_{4}$ & 1C & 70 & $6 \mathrm{Ca}^{4 i}$ & 58 \\
\hline 3 & $\begin{array}{l}4- \\
\mathrm{NO}_{2} \mathrm{C}_{6} \mathrm{H}_{4}\end{array}$ & 1D & 49 & $6 \mathbf{D a}^{4 f}$ & 41 \\
\hline 4 & $2-\mathrm{MeC}_{6} \mathrm{H}_{4}$ & $1 E$ & 40 & $6 \mathbf{E a}^{4 i}$ & 34 \\
\hline 5 & 2-Pyridyl & $1 F$ & 81 & $6 \mathbf{F a}^{8}$ & 60 \\
\hline 6 & 2-Furyl & $1 G$ & 68 & $6 \mathrm{Ga}^{4 c}$ & 51 \\
\hline 7 & 2-Thienyl & 1H & 77 & $6 \mathrm{Ha}^{4 c}$ & 64 \\
\hline
\end{tabular}

Reactions of halides $\mathbf{4}^{c}$

\begin{tabular}{|c|c|c|c|c|c|}
\hline \multirow[b]{2}{*}{ Entry } & \multicolumn{2}{|c|}{ Benzyl chloride } & \multirow{2}{*}{$\begin{array}{l}\text { Conversion } \\
\text { of } 4 / \%\end{array}$} & \multicolumn{2}{|c|}{ Product } \\
\hline & $\mathrm{Ar}$ & & & & Yield/\% \\
\hline 8 & $\begin{array}{l}4- \\
\mathrm{MeOC}_{6} \mathrm{H}_{4}\end{array}$ & 4B & 90 & $6 \mathrm{Ba}$ & 87 \\
\hline 9 & $4-\mathrm{CF}_{3} \mathrm{C}_{6} \mathrm{H}_{4}$ & $4 \mathrm{C}$ & 74 & $6 \mathrm{Ca}$ & 70 \\
\hline 10 & $\begin{array}{l}4- \\
\mathrm{NO}_{2} \mathrm{C}_{6} \mathrm{H}_{4}\end{array}$ & 4D & 62 & 6Da & 54 \\
\hline 11 & $2-\mathrm{MeC}_{6} \mathrm{H}_{4}$ & $4 E$ & 48 & 6Ea & 45 \\
\hline 12 & 2-Pyridyl & $4 F$ & 73 & $6 \mathrm{Fa}$ & 67 \\
\hline 13 & 2-Furyl & 4G & 64 & $6 \mathrm{Ga}$ & 52 \\
\hline 14 & 2-Thienyl & $4 \mathbf{H}$ & 69 & $6 \mathrm{Ha}$ & 64 \\
\hline
\end{tabular}

${ }^{a}$ Each reaction was conducted using boronic acid (1.25 equiv.), $\mathrm{PdCl}_{2}$ (5 mol\%). ${ }^{b}$ Conditions for esters: DPEPhos (5.5 mol\%), $\mathrm{NaHCO}_{3}(2.5$ equiv.) in ethanol, at $80{ }^{\circ} \mathrm{C}$ for $1 \mathrm{~d}$. ${ }^{c}$ Conditions for halides: $\mathrm{Ph}_{3} \mathrm{P}$ (11 mol\%), $\mathrm{Na}_{2} \mathrm{CO}_{3}$ (2.5 equiv.) in $\mathrm{THF} / \mathrm{H}_{2} \mathrm{O}(\mathrm{v} / \mathrm{v}=1 / 1)$, at $40{ }^{\circ} \mathrm{C}$ for $1 \mathrm{~d}$. 
Table 4 Switchable coupling reaction using other boronic acid ${ }^{a}$

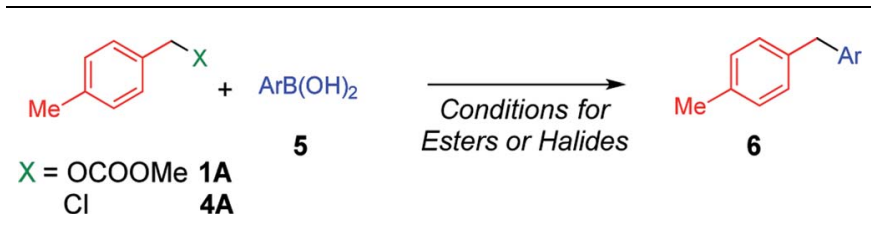

\begin{tabular}{|c|c|c|c|c|c|}
\hline \multirow[b]{2}{*}{ Entry } & \multicolumn{2}{|l|}{ Boronic acid } & \multirow{2}{*}{$\begin{array}{l}\text { Conversion } \\
\text { of } \mathbf{1} / \%\end{array}$} & \multicolumn{2}{|c|}{ Product } \\
\hline & $\mathrm{Ar}$ & & & & Yield/\% \\
\hline 1 & $\begin{array}{l}\text { 4- } \\
\mathrm{MeOC}_{6} \mathrm{H}_{4}\end{array}$ & $5 \mathbf{b}$ & 87 & $\mathbf{6} \mathbf{A} \mathbf{b}^{6 d}$ & 79 \\
\hline 2 & $4-\mathrm{CF}_{3} \mathrm{C}_{6} \mathrm{H}_{4}$ & $5 c$ & 86 & $6 \mathbf{A c}^{9}$ & 75 \\
\hline 3 & $2-\mathrm{MeC}_{6} \mathrm{H}_{4}$ & $5 d$ & 85 & 6Ad ${ }^{10}$ & 70 \\
\hline \multicolumn{6}{|c|}{ Reactions of halide $\mathbf{4 A}^{c}$} \\
\hline \multirow[b]{2}{*}{ Entry } & \multicolumn{2}{|l|}{ Boronic acid } & \multirow{2}{*}{$\begin{array}{l}\text { Conversion } \\
\text { of } 4 / \%\end{array}$} & \multicolumn{2}{|c|}{ Product } \\
\hline & $\mathrm{Ar}$ & & & & Yield/\% \\
\hline 4 & $\begin{array}{l}4- \\
\mathrm{MeOC}_{6} \mathrm{H}_{4}\end{array}$ & $5 \mathbf{b}$ & 70 & $6 \mathrm{Ab}$ & 62 \\
\hline 5 & $4-\mathrm{CF}_{3} \mathrm{C}_{6} \mathrm{H}_{4}$ & $5 c$ & 67 & 6Ac & 60 \\
\hline 6 & $2-\mathrm{MeC}_{6} \mathrm{H}_{4}$ & 5d & 66 & 6Ad & 52 \\
\hline
\end{tabular}

${ }^{a}$ Each reaction was conducted using boronic acid (1.25 equiv.), $\mathrm{PdCl}_{2}$ (5 mol\%). ${ }^{b}$ Conditions for esters: DPEPhos (5.5 mol\%), $\mathrm{NaHCO}_{3}(2.5$ equiv.) in ethanol, at $80{ }^{\circ} \mathrm{C}$ for 1 d. ${ }^{c}$ Conditions for halides: $\mathrm{Ph}_{3} \mathrm{P}$ (11 mol\%), $\mathrm{Na}_{2} \mathrm{CO}_{3}$ (2.5 equiv.) in $\mathrm{THF} / \mathrm{H}_{2} \mathrm{O}(\mathrm{v} / \mathrm{v}=1 / 1)$, at $40{ }^{\circ} \mathrm{C}$ for $1 \mathrm{~d}$.

unreactive under conditions for halides. Instead, bromide $\mathbf{3 A}$ and chloride $\mathbf{4 A}$ furnished $\mathbf{6 A b}-\mathbf{A d}$ in higher yields (Tables 4 and S5 in ESI†). The substrates (benzyl esters or benzyl halides) were successfully switched by changing reaction conditions. Furthermore, the switching mode was not influenced by substituents on the benzene ring of either coupling partner.

Next, we conducted directly competitive reactions of the two substrates (Scheme 3). A mixture of equimolar of benzyl carbonate 1I and benzyl chloride $\mathbf{4 A}$ was reacted with phenylboronic acid $\mathbf{5 a}$. When the reaction was conducted under conditions for esters, only carbonate $\mathbf{1 I}$ was consumed to form 6Ia; ${ }^{9} \mathbf{4 A}$ remained unreacted. To the contrary, only chloride $\mathbf{4 A}$ was consumed under conditions for halides. Hence, this switching system was useful even when the reaction mixture contains both benzyl esters and halides.

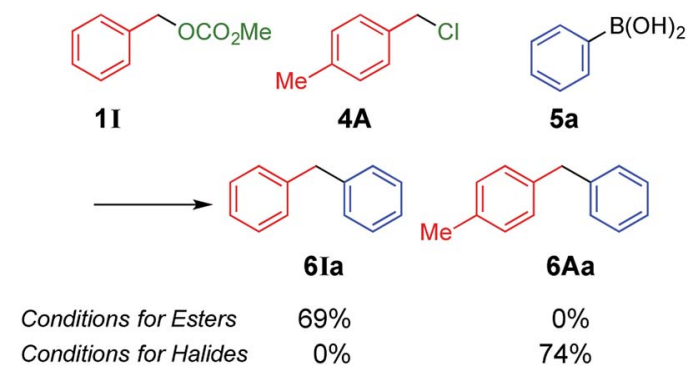

Scheme 3 Competitive reactions using $1 \mathrm{I}$ and $4 \mathrm{~A}$.
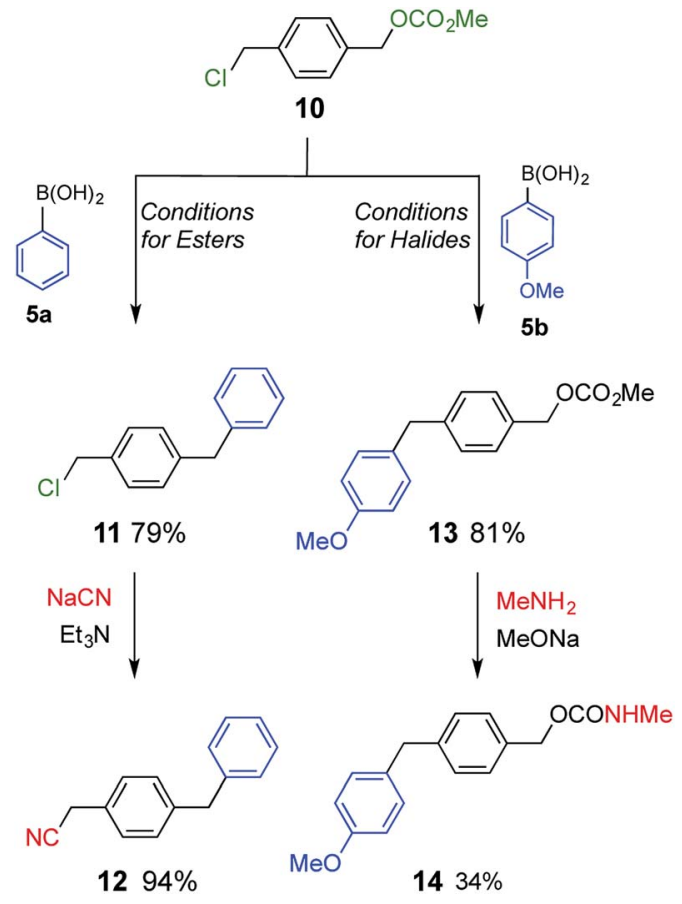

Scheme 4 Intramolecular chemoselective coupling reactions of differently substituted compound 10 .

Compound 10, which possesses both a benzyl ester and benzyl halide moiety was subjected to each of the two reaction conditions (Scheme 4). Compound $\mathbf{1 1}^{\mathbf{1 1}}$ was selectively obtained under conditions for esters. On the other hand, compound $\mathbf{1 3}$ was the product when the reaction was carried out under conditions for halides. Product $\mathbf{1 1}$ was further converted to benzyl cyanide $\mathbf{1 2}^{\mathbf{1 2}}$ upon treatment with sodium cyanide, and product 13 was transformed to benzyl carbamate 14 by nucleophilic substitution with methylamine. ${ }^{13}$ As a result, two different classes of compound were synthesized from common starting material 10.

\section{Conclusions}

A chemoselective Suzuki-Miyaura coupling reaction was achieved by switching reaction conditions. Benzyl carbonates $\mathbf{1}$ and benzyl acetates 2 underwent the coupling reaction with arylboronic acids 5 to afford the corresponding diarylmethanes $\mathbf{6}$ using a Pd catalyst derived from $\mathrm{PdCl}_{2}$ and DPEPhos in ethanol in the presence of $\mathrm{NaHCO}_{3}$ (conditions for esters). Benzyl halides 3 and 4 did not react under the same conditions. On the other hand, when benzyl halides 3 and $\mathbf{4}$ were reacted using a Pd catalyst derived from $\mathrm{PdCl}_{2}$ and $\mathrm{Ph}_{3} \mathrm{P}$ in THF/water in the presence of $\mathrm{Na}_{2} \mathrm{CO}_{3}$ (conditions for halides), the coupling reaction efficiently proceeded to afford diarylmethanes $\mathbf{6}$ while benzyl esters $\mathbf{1}$ and $\mathbf{2}$ did not react. This substrate selectivity depends on the different mode of the oxidative addition, and water displaces one of the phosphine ligands. These switchable conditions facilitated the chemoselectivity even when benzyl esters and benzyl halides coexist in a reaction mixture or molecule. The present system will be a useful tool in elaborate syntheses. 


\section{Experimental}

General

All the reagents and solvents were commercially available and used as received. The ${ }^{1} \mathrm{H}$ NMR spectra were measured on a JEOL 400 spectrometer at $400 \mathrm{MHz}$ with TMS as an internal standard. The ${ }^{13} \mathrm{C}$ NMR spectra were measured on a JEOL 400 spectrometer at $100 \mathrm{MHz}$. The IR spectra were recorded on a JASCO FT/ IR-4100 spectrometer. The melting points were determined on an As-one melting-points apparatus ATM-02, and were uncorrected. High-resolution mass spectra were obtained on an $A B$ SCEIX Triplet TOF 4600 mass spectrometer. Gas chromatography (GC) was performed with Shimadzu GC 8A. Flash column chromatography was performed with Wako-gel C-200 (100-200 mesh, Wako).

Theoretical calculations for the complexes were carried out with $16 \mathrm{~W}$ software. ${ }^{14}$ Optimizations of the ground-state geometries of the complexes were performed by using the this pro density functional theory (DFT). ${ }^{15}$ The LanL2DZ ${ }^{16}$ and 6$31 \mathrm{G}(\mathrm{d}, \mathrm{p})^{17}$ basis sets were used to treat the palladium and all other atoms, respectively. Optimized geometries of the complexes were plotted using GaussView 6.0. ${ }^{18}$

All diarylmethanes 6, 11 and $\mathbf{1 2}$ are commercially available. Hence, the structures of these products were confirmed by comparison of spectral data with those of authentic samples.

\section{General procedure of the Suzuki-Miyaura coupling reaction} under conditions for esters

To a solution of $\mathrm{PdCl}_{2}(1.8 \mathrm{mg}, 10 \mu \mathrm{mol})$, DPEPhos (5.9 mg, 11 $\mu \mathrm{mol}), \mathrm{NaHCO}_{3}(42.0 \mathrm{mg}, 0.5 \mathrm{mmol}$ ), and phenylboronic acid 5a (30.5 $\mathrm{mg}, 0.25 \mathrm{mmol})$ in EtOH $(1.0 \mathrm{~mL})$, 4-methylbenzyl carbonate 1A (36.0 mg, $0.2 \mathrm{mmol}$ ) was added, and the resultant mixture was heated in a screw-capped sealed tube at $80^{\circ} \mathrm{C}$ for 1 d. After treatment with flash column chromatography using hexane to afford 6Aa (26.6 mg, $0.146 \mathrm{mmol}$, yield 73\%), which is confirmed to be not so different from the yield (76\%) determined by ${ }^{1} \mathrm{H}$ NMR. When other conditions and substrates were employed, the experiments were conducted in a similar way.

\section{General procedure of the Suzuki-Miyaura coupling reaction under conditions for halides}

To a solution of $\mathrm{PdCl}_{2}(1.8 \mathrm{mg}, 10 \mu \mathrm{mol}), \mathrm{PPh}_{3}(5.8 \mathrm{mg}, 22 \mu \mathrm{mol})$, $\mathrm{Na}_{2} \mathrm{CO}_{3}$ (53.0 $\mathrm{mg}, 0.5 \mathrm{mmol}$ ), and phenylboronic acid $5 \mathrm{a}$ (30.5 mg, $0.25 \mathrm{mmol})$ in THF and water $(\mathrm{v} / \mathrm{v}=1 / 1)(1.0 \mathrm{~mL}), 4$ methylbenzyl chloride $\mathbf{4 A}(28.1 \mathrm{mg}, 0.2 \mathrm{mmol})$ was added, and the resultant mixture was heated in a screw-capped sealed tube at $40{ }^{\circ} \mathrm{C}$ for $1 \mathrm{~d}$. After treatment with flash column chromatography using hexane to afford 6Aa (28.8 $\mathrm{mg}, 0.158 \mathrm{mmol}$, yield $79 \%)$, which is confirmed to be not so different from the yield (81\%) determined by ${ }^{1} \mathrm{H}$ NMR. When other conditions and substrates were employed, the experiments were conducted in a similar way.

\section{Intermolecular competitive reaction}

Under conditions for esters. To a solution of $\mathrm{PdCl}_{2}(1.8 \mathrm{mg}$, $10 \mu \mathrm{mol})$, DPEPhos (5.9 mg, $11 \mu \mathrm{mol}), \mathrm{NaHCO}_{3}(42.0 \mathrm{mg}, 0.5$ $\mathrm{mmol}$ ), and phenylboronic acid 5a (30.5 $\mathrm{mg}, 0.25 \mathrm{mmol})$ in EtOH $(0.5 \mathrm{~mL})$, a solution of benzyl carbonate 1 I $(30.0 \mathrm{mg}, 0.2$ $\mathrm{mmol})$ and 4-methylbenzyl chloride $\mathbf{4 A}(28.1 \mathrm{mg}, 0.2 \mathrm{mmol})$ in EtOH $(0.5 \mathrm{~mL})$ was added, and the resultant mixture was heated in a screw-capped sealed tube at $80{ }^{\circ} \mathrm{C}$ for $1 \mathrm{~d}$. After treatment with flash column chromatography using hexane to afford 6Ia (23.2 $\mathrm{mg}, 0.138 \mathrm{mmol}$, yield 69\%) without any detectable 6Aa.

Under conditions for halides. To a solution of $\mathrm{PdCl}_{2}(1.8 \mathrm{mg}$, $10 \mu \mathrm{mol}), \mathrm{PPh}_{3}(5.8 \mathrm{mg}, 22 \mu \mathrm{mol}), \mathrm{Na}_{2} \mathrm{CO}_{3}(53.0 \mathrm{mg}, 0.5 \mathrm{mmol})$, and phenylboronic acid $5 \mathrm{a}(30.5 \mathrm{mg}, 0.25 \mathrm{mmol})$ in THF and water $(\mathrm{v} / \mathrm{v}=1 / 1)(0.5 \mathrm{~mL})$, a solution of benzyl carbonate 1 I (30.0 $\mathrm{mg}, 0.2 \mathrm{mmol}$ ) and 4-methylbenzyl chloride $4 \mathrm{~A}(28.1 \mathrm{mg}$, $0.2 \mathrm{mmol})$ in THF and water $(\mathrm{v} / \mathrm{v}=1 / 1)(0.5 \mathrm{~mL})$ was added, and the resultant mixture was heated in a screw-capped sealed tube at $40{ }^{\circ} \mathrm{C}$ for $1 \mathrm{~d}$. After treatment with flash column chromatography using hexane to afford 6Aa $(26.9 \mathrm{mg}, 0.148 \mathrm{mmol}$, yield 74\%) without any detectable 6 Ia.

\section{Chemical conversion of diphenylmethanes}

4-[(4-Methoxyphenyl)methyl]phenylmethyl methyl carbonate (13). White solid; mp 176-177 ${ }^{\circ} \mathrm{C}$. ${ }^{1} \mathrm{H}$ NMR $\left(\mathrm{CDCl}_{3}\right.$, $400 \mathrm{MHz}) \delta 7.31(\mathrm{~d}, J=8.4 \mathrm{~Hz}, 2 \mathrm{H}), 7.23(\mathrm{~d}, J=8.4 \mathrm{~Hz}, 2 \mathrm{H}), 7.15$ $(\mathrm{d}, J=8.4 \mathrm{~Hz}, 2 \mathrm{H}), 6.88(\mathrm{~d}, J=8.8 \mathrm{~Hz}, 2 \mathrm{H}), 5.08(\mathrm{~s}, 2 \mathrm{H}), 4.21(\mathrm{~s}$, $2 \mathrm{H}), 3.79(\mathrm{~s}, 3 \mathrm{H}), 3.76(\mathrm{~s}, 3 \mathrm{H}) ;{ }^{13} \mathrm{C} \mathrm{NMR}\left(\mathrm{CDCl}_{3}, 100 \mathrm{MHz}\right)$ $\delta 159.9,156.0,137.2,130.4,129.2,127.5,127.2,114.0,113.7$, 69.6, 55.3, 54.9, 40.6; IR (neat) 3473, 2958, 1747, 1613, 1515, 1442, 1377, $1247 \mathrm{~cm}^{-1}$; HRMS (ESI-TOF) $m / z[\mathrm{M}+\mathrm{Na}]^{+}$calcd for $\mathrm{C}_{17} \mathrm{H}_{18} \mathrm{O} 4 \mathrm{Na} 309.1097$; found 309.1099.

Cyanation of benzyl chloride 11. To a solution of benzyl chloride 11 (216 mg, $1.0 \mathrm{mmol}$ ) in DMSO (2 mL), were added sodium cyanide $(147 \mathrm{mg}, 3.0 \mathrm{mmol}$ ) and triethylamine (304 mg, $3.0 \mathrm{mmol}$ ), and the resultant mixture was heated at $80^{\circ} \mathrm{C}$ for $1 \mathrm{~d}$. After filtration using a Celite pad, the filtrate was extracted with ethyl acetate $(10 \mathrm{~mL} \times 3)$. The combined organic layer was washed with brine $(10 \mathrm{~mL} \times 1)$, dried over $\mathrm{MgSO}_{4}$, and concentrated under reduced pressure. The residue was treated with flash column chromatography (EtOAc/hexane $=20 / 80$ ) to afford benzyl cyanide 12 (194 mg, $0.94 \mathrm{mmol}$, yield 94\%).

4-[(4-Methoxyphenyl)methyl]phenylmethyl methyl carbamate (14). To a solution of carbonate $13(286 \mathrm{mg}, 1.0 \mathrm{mmol})$ in toluene $(2 \mathrm{~mL})$, were added methylamine $(31.1 \mathrm{mg}, 1.0 \mathrm{mmol})$ and sodium methoxide (54 mg, $1.0 \mathrm{mmol}$ ), and the resultant mixture was heated at $80^{\circ} \mathrm{C}$ for $1 \mathrm{~d}$. After filtration using a Celite pad, the filtrate was extracted with ethyl acetate $(10 \mathrm{~mL} \times 3)$. The combined organic layer was washed with brine $(10 \mathrm{~mL} \times 1)$, dried over $\mathrm{MgSO}_{4}$, and concentrated under reduced pressure. The residue was treated with flash column chromatography (EtOAc/hexane $=50 / 50)$ to afford carbamate 14 (96 mg, $0.34 \mathrm{mmol}$, yield $34 \%$ ). White solid; mp 94-95 ${ }^{\circ} \mathrm{C} .{ }^{1} \mathrm{H}$ NMR $\left(\mathrm{CDCl}_{3}, 400 \mathrm{MHz}\right) \delta 7.28(\mathrm{~d}, J=8.8 \mathrm{~Hz}, 2 \mathrm{H}), 7.20(\mathrm{~d}, J=8.4 \mathrm{~Hz}$, $2 \mathrm{H}), 7.11(\mathrm{~d}, J=8.0 \mathrm{~Hz}, 2 \mathrm{H}), 6.85(\mathrm{~d}, J=8.8 \mathrm{~Hz}, 2 \mathrm{H}), 6.1-6.3(\mathrm{br}$, 1H), $5.04(\mathrm{~s}, 2 \mathrm{H}), 4.19(\mathrm{~s}, 2 \mathrm{H}), 3.72(\mathrm{~s}, 3 \mathrm{H}), 2.69(\mathrm{~s}, 3 \mathrm{H}) ;{ }^{13} \mathrm{C}$ NMR $\left(\mathrm{CDCl}_{3}, 100 \mathrm{MHz}\right) \delta 159.9,155.9,137.1,130.4,129.2,127.5$, 127.2, 114.3, 113.7, 68.4,54.9, 40.8, 21.2; IR (neat) 3319, 2957, 1747, 1657, 1515, 1443, $1273 \mathrm{~cm}^{-1}$; HRMS (ESI-TOF) $\mathrm{m} / \mathrm{z}[\mathrm{M}+$ $\mathrm{Na}]^{+}$calcd for $\mathrm{C}_{17} \mathrm{H}_{19} \mathrm{NO}_{3} \mathrm{Na} 308.1257$, found 308.1258. 


\section{Conflicts of interest}

There are no conflicts to declare.

\section{Notes and references}

1 W. Li, F. Liu, L. Wei and T. Zhao, J. Appl. Polym. Sci., 2007, 104, 3903; T. Akiike and K. Kakutani, Jpn. Kokai Tokkyo Koho, JP Pat, JP 2006143765, 2006; S. I. Nikitenko, Y. Koltypin, D. M. Pickup, E. R. H. Van-Eck and A. Gedanken, Ultrason. Sonochem., 2003, 10, 11.

2 B.-B. Xie, S.-H. Xia, X.-P. Chang and G. Cui, Phys. Chem. Chem. Phys., 2016, 18, 403; P. Prosposito, H. Zhang and M. Glasbeek, J. Sol-Gel Sci. Technol., 2011, 60, 347.

3 M. Nambo, D. Kurihara, T. Yamada, T. Nishiwaki-Ohkawa, N. Kadofusa, Y. Kimata, K. Kuwata, M. Umeda and M. Ueda, Plant Cell Physiol., 2016, 57, 2255; G. Chiellini, G. Nesi, S. Sestito, S. Chiarugi, M. Runfola, S. Espinoza, M. Sabatini, L. Bellusci, A. Laurino, E. Cichero, R. R. Gainetdinov, P. Fossa, L. Raimondi, R. Zucchi and S. Rapposelli, J. Med. Chem., 2016, 59, 9825; T. T. M. Pham and M. Sylvestre, J. Bacteriol., 2013, 195, 3563; W. Eisenreich, N. S. Ladyzhynsky, D. Li, L. Schultz, Z. Wang, S. Macha and A. Barta, PCT Int. Appl., WO Pat, WO, 2010092126, 2010.

4 From benzyl halides: (a) R. B. Bedford, P. B. Brenner, E. Carter, T. W. Carvell, P. M. Cogswell, T. Gallagher, J. N. Harvey, D. M. Murphy, E. C. Neeve, J. Nunn and D. R. Pye, Chem.-Eur. J., 2014, 20, 7935; (b) Y.-Y. Sun, J. Yi, X. Lu, Z.-Q. Zhang, B. Xiao and Y. Fu, Chem. Commun., 2014, 50, 11060; (c) Y.-Q. Zhang, J. Chem. Res., 2013, 37, 375; (d) N. Henry, C. Enguehard-Gueiffier, I. Thery and A. Gueiffier, Eur. J. Org. Chem., 2008, 4824; (e) M. J. Burns, I. J. S. Fairlamb, A. R. Kapdi, P. Sehnal and R. J. K. Taylor, Org. Lett., 2007, 9, 5397; (f) S. M. Norbe and A. L. Monterio, Tetrahedron Lett., 2004, 45, 8225; $(g)$ H. Doucet, M. Santelli and L. Chahen, Synlett, 2003, 1668 From benzyl carbonates: (h) Y. Ohtake, T. Emura, M. Nishimoto, K. Takano, K. Yamamoto, S. Tsuchiya, S.-Y. Yeu, Y. Kito, N. Kimura, S. Takeda, M. Tsukazaki, M. Murakata and T. Sato, J. Org. Chem., 2016, 81, 2148; (i) R. Kuwano and M. Yokogi, Org. Lett., 2005, 7, 945 From benzyl acetates: (j) G. W. Stewart, P. E. Maligres, C. A. Baxter, E. M. Junker, S. W. Krska and J. P. Scott, Tetrahedron, 2016, 72, 3701; (k) R. Kuwano and M. Yokogi, Chem. Commun., 2005, 5899.

5 M. Ohsumi and N. Nishiwaki, ACS Omega, 2017, 2, 7767.

6 Suzuki-Miyaura coupling using other benzylic systems were also reported; however, selective coupling reaction using different reactivity has not been studied. From benzyl pivalates: (a) Q. Chen, X.-H. Fan, L. P. Zhang and L.-M. Yang, $R S C A d v$., 2015, 5, 15338 From benzyl carbamates: (b) X.-X. Wang, M.-J. Luo and J.-M. Lu, Org. Biomol. Chem., 2015, 13, 11438From benzyl ethers: (c) M. Tobisu, J. Zhao, H. Kinuta, T. Furukawa, T. Igarashi and
N. Chatani, Adv. Synth. Catal., 2016, 358, 2417; (d) M. Tobisu, A. Yasutome, H. Kinuta, K. Nakamura and N. Chatani, Org. Lett., 2014, 16, 5572; From benzyl sulfonates: (e) G. Wu, S. Xu, Y. Deng, C. Wu, X. Zhao, W. Ji, Y. Zhang and J. Wang, Tetrahedron, 2016, 72, 8022; $(f)$ X.-X. Wang, B.-B. Xu, W.-T. Song, K.-X. Sun and J.-M. Lu, Org. Biomol. Chem., 2015, 13, 4925 From benzyl sulfones: (g) M. Nambo, E. C. Keske, J. P. G. Rygus, J. C.-H. Yim and C. M. Crudden, ACS Catal., 2017, 7, 1108 From benzyl phosphates: (h) K. Liu, W. Rao, H. Parikh, Q. Li, T. L. Guo, S. Grant, G. E. Kellogg and S. Zhang, Eur. J. Med. Chem., 2012, 47, 125; (i) M. McLaughlin, Org. Lett., 2005, 7, 4875; From phenylacetate: (j) K. Muto, J. Yamaguchi, D. G. Musaev and K. Itami, Nat. Commun., 2015, 6, 7508.

7 K. Das, R. Shibuya, Y. Nakahara, N. Germain, T. Ohshima and K. Mashima, Angew. Chem., Int. Ed., 2012, 51, 150.

8 B. R. P. Reddy, S. Chowdhury, A. Auffrant and C. Gosmini, Adv. Synth. Catal., 2018, 360, 3026.

9 R. J. Procter, J. J. Dunsford, P. J. Rushworth, D. G. Hulcoop, R. A. Layfield and M. J. Ingleson, Chem.-Eur. J., 2017, 23, 15889.

10 F. Forster, T. T. Metsänen, E. Irran, P. Hrobárik and M. Oestreich, J. Am. Chem. Soc., 2017, 139, 16334.

11 G. Schäfer and J. W. Bode, Angew. Chem., Int. Ed., 2011, 50, 10913.

12 Y. Sabnis, P. J. Rosenthal, P. Desai and M. A. Avery, J. Biomol. Struct. Dyn., 2002, 19, 765.

13 P. Tundo, C. R. McElroy and F. Aricò, Synlett, 2010, 10, 1567. 14 M. J. Frisch, G. W. Trucks, H. B. Schlegel, G. E. Scuseria, M. A. Robb, J. R. Cheeseman, G. Scalmani, V. Barone, G. A. Petersson, H. Nakatsuji, X. Li, M. Caricato, A. V. Marenich, J. Bloino, B. G. Janesko, R. Gomperts, B. Mennucci, H. P. Hratchian, J. V. Ortiz, A. F. Izmaylov, J. L. Sonnenberg, D. Williams-Young, F. Ding, F. Lipparini, F. Egidi, J. Goings, B. Peng, A. Petrone, T. Henderson, D. Ranasinghe, V. G. Zakrzewski, J. Gao, N. Rega, G. Zheng, W. Liang, M. Hada, M. Ehara, K. Toyota, R. Fukuda, J. Hasegawa, M. Ishida, T. Nakajima, Y. Honda, O. Kitao, H. Nakai, T. Vreven, K. Throssell, J. A. Montgomery Jr, J. E. Peralta, F. Ogliaro, M. J. Bearpark, J. J. Heyd, E. N. Brothers, K. N. Kudin, V. N. Staroverov, T. A. Keith, R. Kobayashi, J. Normand, K. Raghavachari, A. P. Rendell, J. C. Burant, S. S. Iyengar, J. Tomasi, M. Cossi, J. M. Millam, M. Klene, C. Adamo, R. Cammi, J. W. Ochterski, R. L. Martin, K. Morokuma, O. Farkas, J. B. Foresman and D. J. Fox, Gaussian 16, Revision A.03, Gaussian, Inc., Wallingford, CT, 2016.

15 A. D. Becke, J. Chem. Phys., 1993, 98, 5648.

16 C. Lee, W. Yang and R. G. Parr, Phys. Rev. B, 1988, 37, 785. 17 P. J. Hay and W. R. Wadt, J. Chem. Phys., 1985, 82, 299.

18 R. Dennington, T. Keithand, and J. Millam, Gaussview, Version 6, Semichem Inc, Shawnee Mission, KS, 2016. 